\title{
Air Pollution Associated with Total Suspended Particulate and Particulate Matter in Cement Grinding Plant in Vietnam
}

\author{
Tinh Thai *(D), Ales Bernatik (D) and Petr Kučera \\ Faculty of Safety Engineering, VŠB-Technical University of Ostrava, 70030 Ostrava, Czech Republic; \\ ales.bernatik@vsb.cz (A.B.); petr.kucera@vsb.cz (P.K.) \\ * Correspondence: tinh.xuan.thai.st@vsb.cz
}

check for updates

Citation: Thai, T.; Bernatik, A.; Kučera, P. Air Pollution Associated with Total Suspended Particulate and Particulate Matter in Cement Grinding Plant in Vietnam. Atmosphere 2021, 12, 1707. https:/ / doi.org/10.3390/atmos12121707

Academic Editors: Izabela Sówka, Anetta Drzeniecka-Osiadacz and Tymoteusz Sawiński

Received: 8 November 2021 Accepted: 17 December 2021 Published: 20 December 2021

Publisher's Note: MDPI stays neutral with regard to jurisdictional claims in published maps and institutional affiliations.

Copyright: (c) 2021 by the authors. Licensee MDPI, Basel, Switzerland. This article is an open access article distributed under the terms and conditions of the Creative Commons Attribution (CC BY) license (https:// creativecommons.org/licenses/by/ $4.0 /)$.

\begin{abstract}
Air pollution associated with suspended particles has become a significant concern in Vietnam recently. The study aimed to (1) investigate dust sources; (2) measure concentration levels of Total Suspended Particulate (TSP), Particulate Matter (PM) fractions; (3) identify silica levels and the correlation with respirable particles at a cement grinding plant in Vietnam. A total of 312 samples (52 TSP, $160 \mathrm{PMs}$ ) at 13 processes were measured using the direct-reading dust meter. The silica composition was analyzed in a certified laboratory using the X-ray fluorescence (XRF) technique. SPSS version 26 for Window was used to analyze the data. The operations of the cement grinding plant created multiple dust sources from the jetty to the cement dispatch process. The TSP levels ranged $0.06-38.24 \mathrm{mg} \mathrm{m}^{-3}$, and $40.38 \%(n=21)$ TSP samples exceeded the Permissible Exposure Limit (PEL) for an 8-h working shift. Besides that, there was a wide range and significant concentration levels of PMs in the cement processes. The levels of PMs were $\mathrm{PM}_{1}$ $\left(0.00-0.06 \mathrm{mg} \mathrm{m}^{-3}\right), \mathrm{PM}_{2.5}\left(0.01-0.83 \mathrm{mg} \mathrm{m}^{-3}\right), \mathrm{PM}_{4}\left(0.02-4.59 \mathrm{mg} \mathrm{m}^{-3}\right), \mathrm{PM}_{7}\left(0.03-16.94 \mathrm{mg} \mathrm{m}^{-3}\right)$, and $\mathrm{PM}_{10}\left(0.04-26.85 \mathrm{mg} \mathrm{m}^{-3}\right)$. The highest mean levels of PMs factions were measured at the pre-grinding process. The inefficient operation of the dust collector contributed a significant factor to the dust dispersion in this process. The silica's mean (SD) composition in respirable dust was $20.4 \%$ (0.86) and was not significantly different amongst the processes. There was a significant correlation between the levels of respirable dust and silica exposure in the cement grinding plant $(r=0.99)$. The improvement of indoor air quality is needed to prevent health effects on cement workers.
\end{abstract}

Keywords: air pollution; cement manufacturing; health effects; particulate matter; total suspended particulates

\section{Introduction}

Air pollution is one of the most significant environmental risks to health globally, significantly affecting low and middle-income countries. The common indicators used for evaluating air quality and health effects are Total Suspended Particulate (TSP) and Particulate Matter (PM) [1]. According to the International Standardization Organization (ISO), "Dust is small solid particles, conventionally taken as those particles below $75 \mu \mathrm{m}$ in diameter, which settle out under their own weight but which may remain suspended for some time" [2]. Dust is defined as small, dry, solid particles projected into the air by natural forces, such as wind, volcanic eruption, and by mechanical or artificial processes such as crushing, grinding, milling, drilling, demolition, shoveling, conveying, screening, bagging, and sweeping. Dust particles are usually in size range from about 1 to $100 \mu \mathrm{m}$ in diameter, and they settle slowly under the influence of gravity [3]. Particulate matter is a mixture of solid and liquid particles in the air that is small enough not to settle onto the Earth's surface under the influence of gravity, classified by aerodynamic diameter [1]. Depending on the aerodynamic diameter, the airborne particle fractions are inhaled and deposited in the various regions of the respiratory system. Inhalable particulate fraction is that fraction of a dust cloud that can be breathed into the nose and mouth. Thoracic particulate fraction 
is that fraction that can penetrate the head airways and enter the airways of the lung. The respirable particulate fraction is that fraction of inhaled airborne particles that can penetrate beyond the terminal bronchioles into the gas-exchange region of the lungs $[2,4]$.

Silicon dioxide $\left(\mathrm{SiO}_{2}\right)$, commonly knowns as silica, is one of the most prevalent chemical compounds in the earth's crust. Materials containing silica are extensively used in various industries such as construction, cement industry, and mining [5]. Prolonged occupational exposure to silica has long been recognized as a threat to workers' health, causing autoimmune diseases, silicosis, tuberculosis, and lung cancer [6-9]. Besides that, silica-exposed workers are at an increased risk of heart disease, especially pulmonary heart disease [10]. The cement industry is one of the significant emission sources of suspended particles containing silica. In the cement manufacturing line, suspended particles were generated and dispersed to the workplace environment from the crusher, packing, cement mill, and raw mill [11]. Typically, particle sizes of Portland cement vary from $<1 \mu \mathrm{m}$ to $100 \mu \mathrm{m}$ in diameter [12]. The fine particles are potentially inhaled and penetrate deep into the respiratory system, causing health effects. The previous studies reported that the total dust and respirable dust concentration exceeded the Permissible Exposure Limit (PEL) in the cement manufacturing processes. These processes consisted of the crusher, raw mill, kiln, cement mill, and packing machine $[11,13,14]$. Prolonged exposure to cement dust can potentially lead to chronic bronchitis, respiratory diseases, and cancer [15-23]. Exposure to cement dust caused different effects on workers' health, such as cough, chest tightness, impairment of lung function, irritation of eyes, runny eyes, skin irritation, stomachache, headache, and hemoglobin concentration $[15,24,25]$.

In Vietnam, the cement industry has been developing since 1899 and plays an important role in economic development. In 2019, Vietnam was the third largest cement producer in the world with a production volume of 99 million tons. Until 2020, 90 cement manufacturing lines have been constructed and operated in the country with a capacity of $108 \mathrm{Mt}$ [26]. Furthermore, the Vietnamese authorities have approved the development strategy of the cement industry from 2021 to 2030, with an increased capacity of $150 \mathrm{Mt}$ per annum [27]. However, cement workers are exposed to various harmful factors in the workplace, which leads to occupational diseases. The typical harmful elements in the cement manufacturing processes were noise and particle matter [14,21,25,28,29].

Ho Chi Minh City (HCMC) is the largest city located in the South of Vietnam, where growing industrial activity contributed to air pollution. Air pollution is a significant issue reducing the quality of life of HCMC's residents [30]. A limited number of studies reported the PM concentration levels in the ambient environment and their effects in HCMC. A study in HCMC in 2017 reported that the annual $\mathrm{PM}_{2.5}$ concentration level was $0.03 \mathrm{mg} \mathrm{m}^{-3}$, which exceeded the Vietnamese National Standard $\left(0.025 \mathrm{mg} \mathrm{m}^{-3}\right)$ for 14 days and exceeded the $\mathrm{WHO}$ guideline for $\mathrm{PM}_{2.5}\left(0.01 \mathrm{mg} \mathrm{m}^{-3}\right)$ for 222 days [31]. Other studies published the adverse impact of coarse particulate matter $\left(\mathrm{PM}_{10}\right)$ on the population health in HCMC [32-35]. However, these studies have just focused on the evaluation of the PMs in the ambient environment. There is currently no research to evaluate the different particle size distributions and silica concentration in the cement plant. This study aimed to identify dust sources, assess the distribution of TSP, and different PMs fraction sizes in the cement grinding processes. In addition, the study aimed to determine the correlation between respirable dust concentration levels and silica exposure.

\section{Materials and Methods}

\subsection{Study Site Information}

This study was conducted in May 2021 at a cement grinding plant located in Ho Chi Minh City, in the South of Vietnam. The city consists of 19 urban and five suburban districts with a total area of $2061 \mathrm{~km}^{2}$ and more than 9 million people [36]. The city has a hot and humid climate year-round, with an average temperature of $27.5^{\circ} \mathrm{C}$. The city has two seasons which include the rainy season (May-November) and the dry season (DecemberApril) [34]. The study site was established in 2003, and consists of 78 full-time employees 
with the capacity of 500,000 tons per annual. The operation of the plant involves the participation of direct workers from the production, maintenance, and logistic department.

The main processes of the cement grinding plant consist of unloading raw materials at the jetty, raw materials storage and handling, pre-grinding with crusher, cement grinding in the ball mill, cement storage, and cement dispatch. The raw materials used in the cement grinding plant are clinker, limestone, gypsum, pozzolana, and slag. At the study site, two cement products are produced, which include cement bag $50 \mathrm{~kg}$ with clinker factor $(56 \%)$, limestone (19\%), gypsum (4\%), other additives, and bulk cement used for industrial purposes with clinker factor (73-75\%), limestone (12.5\%), gypsum (4\%), and other additives.

\subsection{Study and Sampling Design}

The authors surveyed the cement grinding processes under the support of the process engineer and departments representatives to identify dust sources and job group characteristics (daily tasks, number of exposed workers, and duration) in a working shift. The mean duration of working in each process was calculated based on the actual operation hours in 2020 of the crane at the jetty, ball mill, packing machine, and bulk dispatch. Based on the dust sources in the cement grinding plant, a sampling map of the TSP and PM samples was designed using Google Earth Pro and presented in Figure 1.

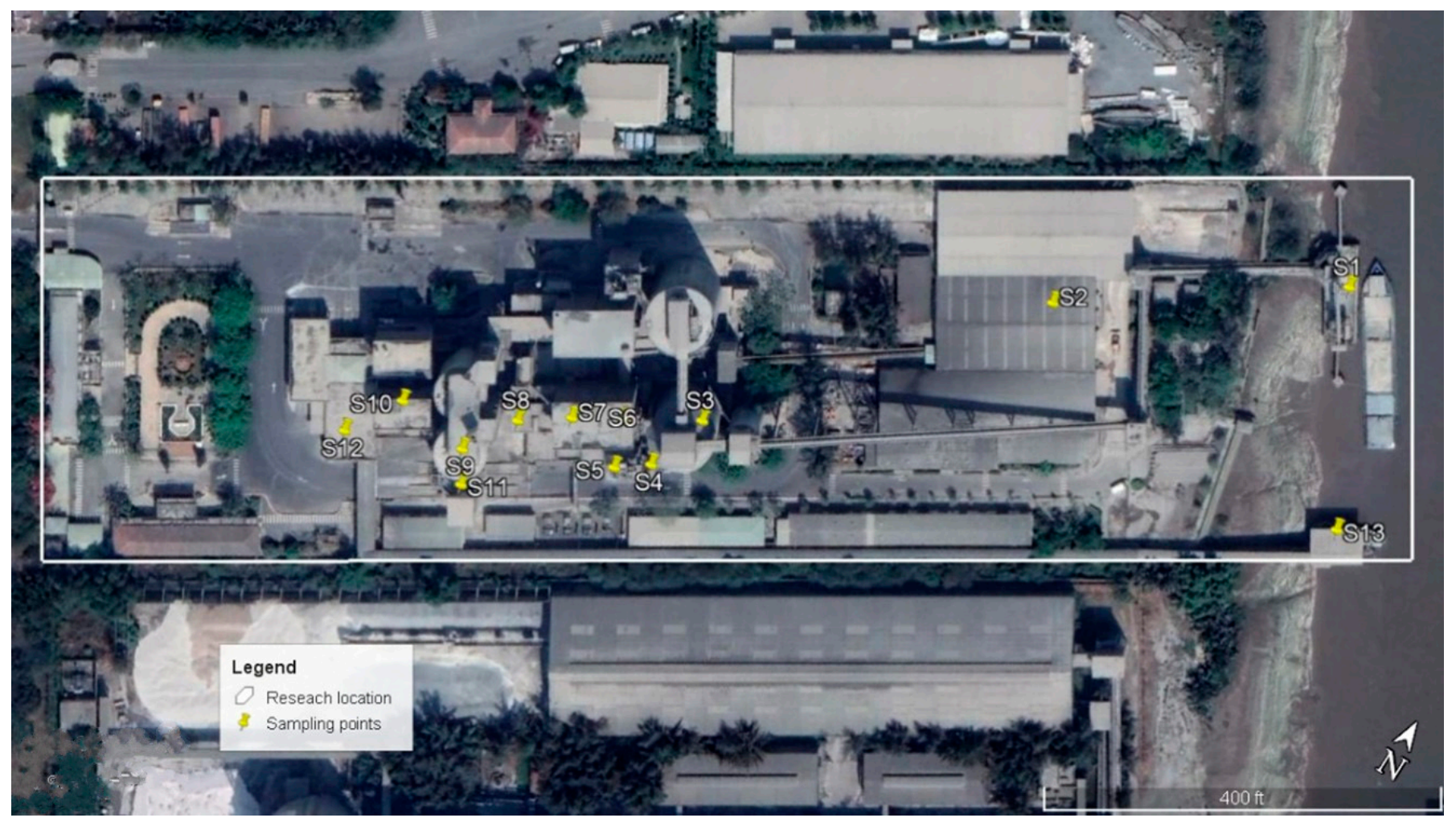

Figure 1. The layout of dust sampling.

\subsection{Dust Monitoring Procedure}

A total of 52 TSP samples and 260 samples of $\mathrm{PM}_{1}, \mathrm{PM}_{2.5}, \mathrm{PM}_{4}, \mathrm{PM}_{7}$, and $\mathrm{PM}_{10}$ were measured in 13 sub-processes of the grinding plant during the working shifts. At each measurement point, the dust concentration level was measured at the worker's breathing zone during each of the four different working hours (7:30-9:30; 9:30-11:30; 12:30-14:30; 14:30-16:30). These hours cover the duration of the working shift and represent the dust mass concentration level for all workers at the site, since operational processes are the same for all shifts. 
In order to measure the dust concentration in indoor workplaces, a direct-reading dust mass monitor (MET ONE AEROCET 531S (USA)) was used. The Aerocet 531S counts and sizes particles in different size ranges then use a proprietary algorithm to convert count data to mass measurement. The mass concentration precision of this equipment is $0.0001 \mathrm{mg} \mathrm{m}^{-3}$. Before measuring, the dust meter was fully charged, performed zero tests in a clean environment, was calibrated by a qualified center, and was valid until April 2022. Next, the dust meter was set up in mass mode, and the $\mathrm{PM}_{1}, \mathrm{PM}_{2.5}, \mathrm{PM}_{4}, \mathrm{PM}_{7}, \mathrm{PM}_{10}$, and TSP mass concentration levels were measured and recorded on the paper sheet for all processes. The measurement process complied with the dust measurement protocol regulated by the Vietnamese standards (QCVN 02:2019/BYT) [37].

The time-weighted average (TWA) concentration for an eight-hour working shift was calculated by using the Formula (1) [38].

$$
T W A\left(m g m^{-3}\right)=\frac{C_{1} \times T_{1}+C_{2} \times T_{2}+\ldots+C_{n} \times T_{n}}{8}
$$

where: TWA $\left(\mathrm{mg} \mathrm{m}^{-3}\right)$ is the equivalent exposure limit for an eight-hour working shift; $C_{n}$ $\left(\mathrm{mg} \mathrm{m}^{-3}\right),(n=4)$ is the dust mass concentration level represents for a period of time (T); $T_{n}$ (hours) is the duration in hours of the exposure in the concentration (C).

The excessive TSP, PMs for an eight-hour working shift at the processes was identified by comparing to the Permissible Exposure Limit (PEL) regulated by the Vietnamese standard (QCVN 02:2019/BYT) [37].

\subsection{Silica Analysis and Processing}

In order to identify the silica concentration in respirable dust, five samples of accumulated dust that settled on the top surface of the machine or structure at the cement grinding, packing machine, truck dispatch, barge dispatch, and bulk dispatch were taken. Next, they were sealed in plastic bags and analyzed in the certified laboratory (Vilas 100). The ARL QUANT'X EDXRF analyzer (Thermo Scientific, Paisley, UK), operating using the $\mathrm{X}$-ray fluorescence (XRF) technique was used to measure the composition of silica (silicon dioxide) with a minimum detection limit of $0.003 \%$. Finally, the concentration of free silica in respirable dust was calculated using the Formula (2) [37].

$$
C_{\text {silica }}\left(m g m^{-3}\right)=\frac{C_{\text {respirable dust }}\left(m g m^{-3}\right) \times \text { Free silica }(\%)}{100}
$$

where: $C_{\text {silica }}\left(\mathrm{mg} \mathrm{m}^{-3}\right)$ : concentration of free silica in respirable dust; $C_{\text {respirable dust }}\left(\mathrm{mg} \mathrm{m}^{-3}\right)$ : concentration of respirable dust $\left(\mathrm{PM}_{4}\right)$.

SPSS version 26 for Windows was used to analyze the data, and Pearson analysis was used to identify the correlation between the levels of respirable concentration and silica exposure in the cement grinding processes.

\section{Results and Discussion}

\subsection{Dust Sources and Exposed Job Groups in the Cement Grinding Processes}

The operation of the cement grinding plant generates suspended particulates from all processes. The survey-based-process observation revealed the various dust sources in the processes where cement workers are exposed daily. In the jetty, the dust was generated in the opening space of the hopper and dispersed to the surrounding areas during unloading raw materials. The belt conveyor system is typically used to transfer raw materials to the storage or silos. However, the transferring of raw materials generated suspended dust at the changing-direction points, which raw materials fall freely to a lower position. In the pre-grinding process, the crusher was used to reduce raw materials' size before feeding the cement mill. In this process, dust came up at the changing-direction points underneath the feed bin connected to the belt conveyor. The efficient operational control of dust collectors in this process plays an essential role in controlling dust dispersion. After a long period 
of operation, raw materials shall build up inside the system that potentially reduces the airflow of the dust collector. In the cement grinding process, a closed system consists of ball mill, separator, primary bag filter, and air-slide was used. The main dust sources came from the primary bag filter's stack, which mainly emitted the ambient environment. In the final process, the primary dust sources were generated while operating the packing machine and loading cement bags to customer's truck or barge. While running the packing machine, cement leaked from the spout and fell freely to the ground, resulting in dust dispersion. The delivering of cement bags to a customer's truck or barge generated dust. Some dust sources in the cement grinding processes are present in Figure 2.

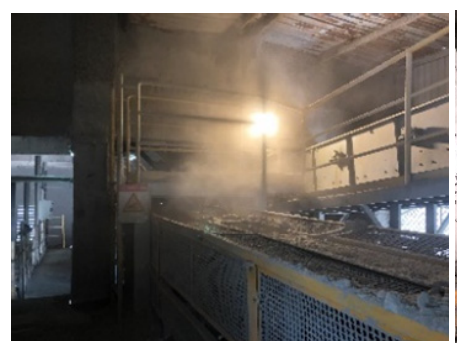

(a)

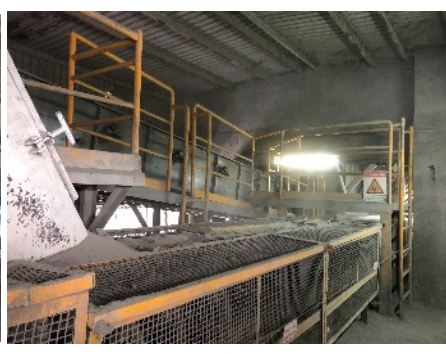

(b)

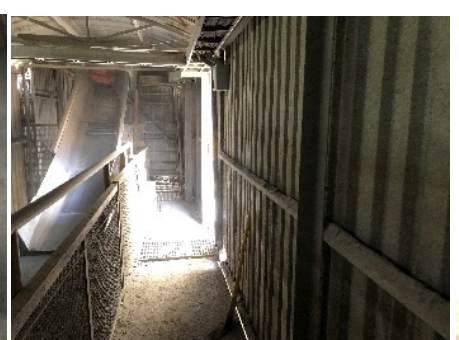

(c)

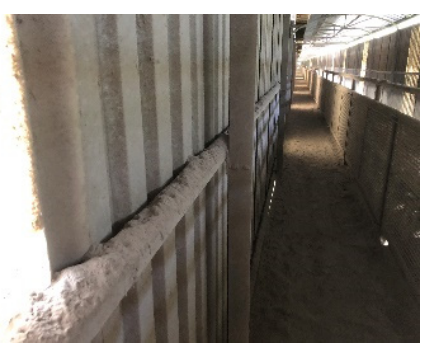

(d)

Figure 2. Some dust sources in the cement grinding plant: (a) mill inlet; (b) underneath of feed-bin; (c) at changed-direction point; (d) accumulated dust along dispatch belt conveyor.

In a basic working shift, cement workers in each job group are exposed to dust sources in the process. The operational control of the cement grinding processes from jetty to cement mill output was remotely performed by process operators in the central control room (CCR). During mill operation, process operators perform an interval inspection in the grinding processes every $60 \mathrm{~min}$. In the dispatch process, the operation of the packing machine and delivery of cement bag to customer vehicles was manually performed by the operator and stevedore. The packer operator and stevedore were directly exposed to cement dust sources while operating the packing machine and the bag dispatch system. The job group characteristics and exposure duration in each process are summarized in Table 1.

Table 1. Job group characteristics and exposure duration in the cement grinding process.

\begin{tabular}{|c|c|c|c|c|c|c|}
\hline \multirow{2}{*}{ Process } & \multirow{2}{*}{ Job Group } & \multirow{2}{*}{ Department } & \multirow{2}{*}{$\begin{array}{l}\text { No. Exposed } \\
\text { Worker }\end{array}$} & \multicolumn{2}{|c|}{$\begin{array}{c}\text { Exposure Duration in } 2020 \\
\text { (hrs/Shift) }\end{array}$} & \multirow{2}{*}{ Key Daily Tasks } \\
\hline & & & & Mean (SD) & Range & \\
\hline Jetty & $\begin{array}{l}\text { Crane } \\
\text { operator }\end{array}$ & Production & 4 & $2.17(0.77)$ & $0.93-3.55$ & $\begin{array}{l}\text { Operation of the crane to } \\
\text { unload raw materials } \\
\text { from the barges; }\end{array}$ \\
\hline Pre-grinding & $\begin{array}{l}\text { Process } \\
\text { operator }\end{array}$ & Production & 8 & $4.01(1.36)$ & $1.69-5.97$ & $\begin{array}{l}\text { Ensure the stable } \\
\text { operation of the crusher } \\
\text { and other equipment; } \\
\text { Remotely control from } \\
\text { CCR; }\end{array}$ \\
\hline Cement mill & $\begin{array}{l}\text { Process } \\
\text { operator }\end{array}$ & Production & 8 & $4.01(1.36)$ & $1.69-5.97$ & $\begin{array}{l}\text { Ensure the stable } \\
\text { operation of the mill and } \\
\text { equipment; Remotely } \\
\text { control from CCR; }\end{array}$ \\
\hline $\begin{array}{l}\text { Cement } \\
\text { dispatch }\end{array}$ & & & & & & \\
\hline
\end{tabular}


Table 1. Cont.

\begin{tabular}{|c|c|c|c|c|c|c|}
\hline \multirow{2}{*}{ Process } & \multirow[t]{2}{*}{ Job Group } & \multirow[t]{2}{*}{ Department } & \multirow{2}{*}{$\begin{array}{l}\text { No. Exposed } \\
\text { Worker }\end{array}$} & \multicolumn{2}{|c|}{$\begin{array}{c}\text { Exposure Duration in } 2020 \\
\text { (hrs/Shift) }\end{array}$} & \multirow[t]{2}{*}{ Key Daily Tasks } \\
\hline & & & & Mean (SD) & Range & \\
\hline $\begin{array}{l}\text { Packing } \\
\text { machine }\end{array}$ & $\begin{array}{l}\text { Packer } \\
\text { operator }\end{array}$ & Production & 12 & $1.80(0.65)$ & $0.35-2.34$ & $\begin{array}{l}\text { Operation of the packing } \\
\text { machine manually to } \\
\text { pack cement bag as } \\
\text { customer's request; }\end{array}$ \\
\hline $\begin{array}{l}\text { Cement bag } \\
\text { dispatch }\end{array}$ & Stevedore & $\begin{array}{l}\text { Logistics } \\
\text { (third-party) }\end{array}$ & 12 & $1.80(0.65)$ & $0.35-2.34$ & $\begin{array}{c}\text { Loading cement bag to } \\
\text { customer's trucks and } \\
\text { barges; }\end{array}$ \\
\hline \multirow{2}{*}{$\begin{array}{l}\text { Bulk dispatch } \\
\text { system }\end{array}$} & $\begin{array}{l}\text { Logistic } \\
\text { operator }\end{array}$ & Logistics & 8 & $2.56(0.96)$ & $1.23-4.40$ & $\begin{array}{l}\text { Remotely operating the } \\
\text { bulk dispatch system in } \\
\text { CCR; }\end{array}$ \\
\hline & Stevedore & $\begin{array}{l}\text { Logistics } \\
\text { (contractor) }\end{array}$ & 2 & $2.56(0.96)$ & $1.23-4.40$ & $\begin{array}{l}\text { Manually opening and } \\
\text { closing the cap of the } \\
\text { bulk tanker; }\end{array}$ \\
\hline
\end{tabular}

\subsection{Excessive Total Dust Concentration in the Cement Grinding Processes}

The results of dust surveillance at the study site revealed that the TSP samples $(40.38 \%$, $n=21$ ) in four out of six processes exceeded the PEL for an 8-h working shift, regulated by Vietnamese Standard (QCVN 02:2019/BYT, TWA $=4 \mathrm{mg} \mathrm{m}^{-3}$ ). The processes with the excessive TSP against the PEL consisted of raw material storage and handling $\left(18.22 \mathrm{mg} \mathrm{m}^{-3}\right)$; pre-grinding (under the feed bin connecting to the belt conveyor $\left(25.62 \mathrm{mg} \mathrm{m}^{-3}\right)$ ); cement grinding (5.63 $\left.\mathrm{mg} \mathrm{m}^{-3}\right)$, and cement dispatch (5.34 $\mathrm{mg} \mathrm{m}^{-3}$ at packing machine; $11.55 \mathrm{mg} \mathrm{m}^{-3}$ at truck loader and $13.40 \mathrm{mg} \mathrm{m}^{-3}$ at barge loading system). The TSP at the remaining processes met the regulated PEL, and included unloading raw material at the jetty $\left(0.21 \mathrm{mg} \mathrm{m}^{-3}\right)$; raw material storage $\left(0.83 \mathrm{mg} \mathrm{m}^{-3}\right)$; mill output $\left(0.57 \mathrm{mg} \mathrm{m}^{-3}\right)$ at cement grinding process; cement transferring $\left(0.21-0.45 \mathrm{mg} \mathrm{m}^{-3}\right)$; and the bulk dispatch $\left(0.15 \mathrm{mg} \mathrm{m}^{-3}\right)$. The TSP at the study site is given in Table 2 .

Table 2. The TSP at the cement grinding plant.

\begin{tabular}{|c|c|c|c|c|c|c|}
\hline \multirow{2}{*}{\multicolumn{2}{|c|}{ Process }} & \multirow{2}{*}{\multicolumn{2}{|c|}{ Sub-Process }} & \multicolumn{2}{|c|}{ TSP $\left(\mathrm{mg} \mathrm{m}^{-3}\right)$} & \multirow{2}{*}{$\begin{array}{c}\text { PEL } \\
\left(\mathrm{mg} \mathrm{m}^{-3}\right)\end{array}$} \\
\hline & & & & Mean (SD) & Range & \\
\hline P1 & Jetty & S1 & Unloading raw material & $0.21(0.11)$ & $0.11-0.31$ & 4.0 \\
\hline \multirow[t]{2}{*}{ P2 } & $\begin{array}{l}\text { Raw materials storage } \\
\text { and handling }\end{array}$ & S2 & $\begin{array}{c}\text { Raw material storage and } \\
\text { preparation }\end{array}$ & $0.83(0.42)$ & $0.21-1.14$ & 4.0 \\
\hline & & S3 & $\begin{array}{l}\text { Connecting point between } \\
\text { clinker silo and belt conveyor }\end{array}$ & $18.22(15.16)$ & $3.11-38.24$ & 4.0 \\
\hline \multirow[t]{2}{*}{ P3 } & Pre-grinding & S4 & Roller press & $2.93(1.28)$ & $1.55-4.28$ & 4.0 \\
\hline & & S5 & Feeding bin and conveyor & $25.62(9.49)$ & $15.58-35.13$ & 4.0 \\
\hline \multirow[t]{2}{*}{ P4 } & Cement grinding & S6 & Mill input & $5.63(3.95)$ & $3.42-11.54$ & 4.0 \\
\hline & & S7 & Mill output & $0.57(0.29)$ & $0.21-0.81$ & 4.0 \\
\hline \multirow[t]{2}{*}{ P5 } & $\begin{array}{l}\text { Cement transferring and } \\
\text { silo }\end{array}$ & S8 & Air-slide & $0.45(0.34)$ & $0.12-0.84$ & 4.0 \\
\hline & & S9 & Cement silo & $0.21(0.08)$ & $0.11-0.29$ & 4.0 \\
\hline \multirow[t]{4}{*}{ P6 } & Cement dispatch & $\mathrm{S} 10$ & Packing machine & $5.34(1.67)$ & $3.52-7.45$ & 4.0 \\
\hline & & S11 & Bulk dispatch & $0.15(0.11)$ & $0.06-0.31$ & 4.0 \\
\hline & & $\mathrm{S} 12$ & Bag dispatch by truck & $11.55(7.74)$ & $4.13-18.84$ & 4.0 \\
\hline & & S13 & Bag dispatch by barge & $13.40(7.30)$ & $5.81-23.00$ & 4.0 \\
\hline
\end{tabular}


The highest TSP concentration level was measured at the connecting point between the feed bin and the belt conveyor with $25.62 \mathrm{mg} \mathrm{m}^{-3}$ and was 6.4 times higher than the PEL for an 8-h working shift. The free-falling of raw materials from the feed-bin to the conveyor generated the pressure inside the belt conveyor. The dust collector is installed to balance the pressure inside the belt conveyor and control the dust emission. However, the inefficient operation of the dust collector contributed a significant factor to the dust dispersion in this process. The measurement in the bulk dispatch process recorded the lowest TSP concentration levels, with $0.15 \mathrm{mg} \mathrm{m}^{-3}$.

The packing operator exposed excessive TSP levels for an eight-hour working shift limit at two sub-processes of the packing dispatch process. The measured TSP at the truck and barge loading process was $11.55 \mathrm{mg} \mathrm{m}^{-3}, 2.9$ times higher than the PEL and $13.40 \mathrm{mg} \mathrm{m}^{-3}$, 3.4 times higher than the PEL, respectively. The dispatch process was operating outdoors and had no dust collector because of the initial design. When operators dropped the cement bag from the loading chute to the truck or the barge, it generated and dispersed cement dust to the environment. The particulate size distribution, cement bag quality, and the height of free falling of the cement bag were the significant factors that caused the dust dispersion.

Previous studies reported the excessive TSP in some cement manufacturing processes. A study conducted in 2005 at a cement factory in Tanzania showed that the TSP at some processes exceeded the PEL, such as crane $\left(38.64 \mathrm{mg} \mathrm{m}^{-3}\right)$, packing $\left(21.30 \mathrm{mg} \mathrm{m}^{-3}\right)$, and crusher $\left(13.48 \mathrm{mg} \mathrm{m}^{-3}\right)$. The TSP at other processes was lower than the PEL, which included cement mill (3.23 $\left.\mathrm{mg} \mathrm{m}^{-3}\right)$, kiln $\left(2.87 \mathrm{mg} \mathrm{m}^{-3}\right)$, and raw mill $\left(1.85 \mathrm{mg} \mathrm{m}^{-3}\right)$ [39]. Another study conducted in a cement factory in Iran in 2009 presented that the total dust was at a high level in some processes, including crusher $\left(20.84 \mathrm{mg} \mathrm{m}^{-3}\right)$, packing $\left(17.29 \mathrm{mg} \mathrm{m}^{-3}\right)$, kiln $\left(16.78 \mathrm{mg} \mathrm{m}^{-3}\right)$, cement mill $\left(14.90 \mathrm{mg} \mathrm{m}^{-3}\right)$, and raw mill $\left(10.44 \mathrm{mg} \mathrm{m}^{-3}\right)$ [40]. Another study on cement dust published that the TSP in some processes exceeded the PEL and included crusher $\left(27.49 \mathrm{mg} \mathrm{m}^{-3}\right)$, packing $\left(16.90 \mathrm{mg} \mathrm{m}^{-3}\right)$, cement mill $\left(13.07 \mathrm{mg} \mathrm{m}^{-3}\right)$, and raw mill (10.31 $\mathrm{mg} \mathrm{m}^{-3}$ ) [11]. The previous studies showed that the TSP at many processes in cement plants, such as cement mill, packing, raw mill, and crusher, exceeded the PEL, and these findings were comparable with the results in this study. In addition, the measurement results reported the TSP in other processes in a cement grinding plant such as jetty, material storage, pre-grinding, cement mill input and output, truck dispatch, and barge dispatch. The works provided the database of the TSP in all processes of the cement grinding plant for further research.

\subsection{Wide Range Distribution of Particulate Matters in the Cement Grinding Process}

Data obtained with this study showed a wide range distribution of particulate matter fractions in the workplace environment of the cement grinding plant. In addition, the measurements revealed the significant concentration levels of particulate matter in the whole process. The concentration levels of PMs were in the range of $\mathrm{PM}_{1}\left(0.004-0.06 \mathrm{mg} \mathrm{m}^{-3}\right)$, $\mathrm{PM}_{2.5}\left(0.01-0.83 \mathrm{mg} \mathrm{m}^{-3}\right), \mathrm{PM}_{4}\left(0.02-4.59 \mathrm{mg} \mathrm{m}^{-3}\right), \mathrm{PM}_{7}\left(0.03-16.94 \mathrm{mg} \mathrm{m}^{-3}\right)$, and $\mathrm{PM}_{10}$ $\left(0.04-26.85 \mathrm{mg} \mathrm{m}^{-3}\right)$. The distribution of the particulate matter fractions at the study site is presented in Figure 3.

The measurement results divided the PMs into two principal groups: coarse particles, mostly larger than $2.5 \mu \mathrm{m}$ in aerodynamic diameter, and fine particles, mostly smaller than $2.5 \mu \mathrm{m}$ in aerodynamic diameter $\left(\mathrm{PM}_{2.5}\right)$.

The mean (SD) levels of $\mathrm{PM}_{2.5-1}$ were $0.14(0.17) \mathrm{mg} \mathrm{m}^{-3}, 0.02(0.01) \mathrm{mg} \mathrm{m}^{-3}$, respectively. The lowest level of $\mathrm{PM}_{2.5-1}$ was recorded at the jetty and the bulk dispatch process, respectively. The highest level of $\mathrm{PM}_{2.5-1}$ was measured at the connecting point between the feeding bin and the belt conveyor, a sub-process of the pre-grinding process. The $\mathrm{PM}_{2.5-1}$ concentration levels were significantly different amongst processes. The mean (SD) $\mathrm{PM}_{2.5-1}$ level in the cement grinding processes was in jetty $\left(0.02(0.01), 0.01(0.00) \mathrm{mg} \mathrm{m}^{-3}\right.$, respectively); raw material storage and handling $\left(0.14(0.17), 0.02(0.01) \mathrm{mg} \mathrm{m}^{-3}\right.$, respectively); pre-grinding (0.33 (0.29), $0.03(0.02) \mathrm{mg} \mathrm{m}^{-3}$, respectively); cement grinding 
(0.08 (0.07), $0.02(0.01) \mathrm{mg} \mathrm{m}^{-3}$, respectively); cement transferring and storage (0.03 (0.02), $0.02(0.00) \mathrm{mg} \mathrm{m}^{-3}$, respectively); and cement dispatch $\left(0.15(0.11), 0.02(0.01) \mathrm{mg} \mathrm{m}^{-3}\right.$, respectively).
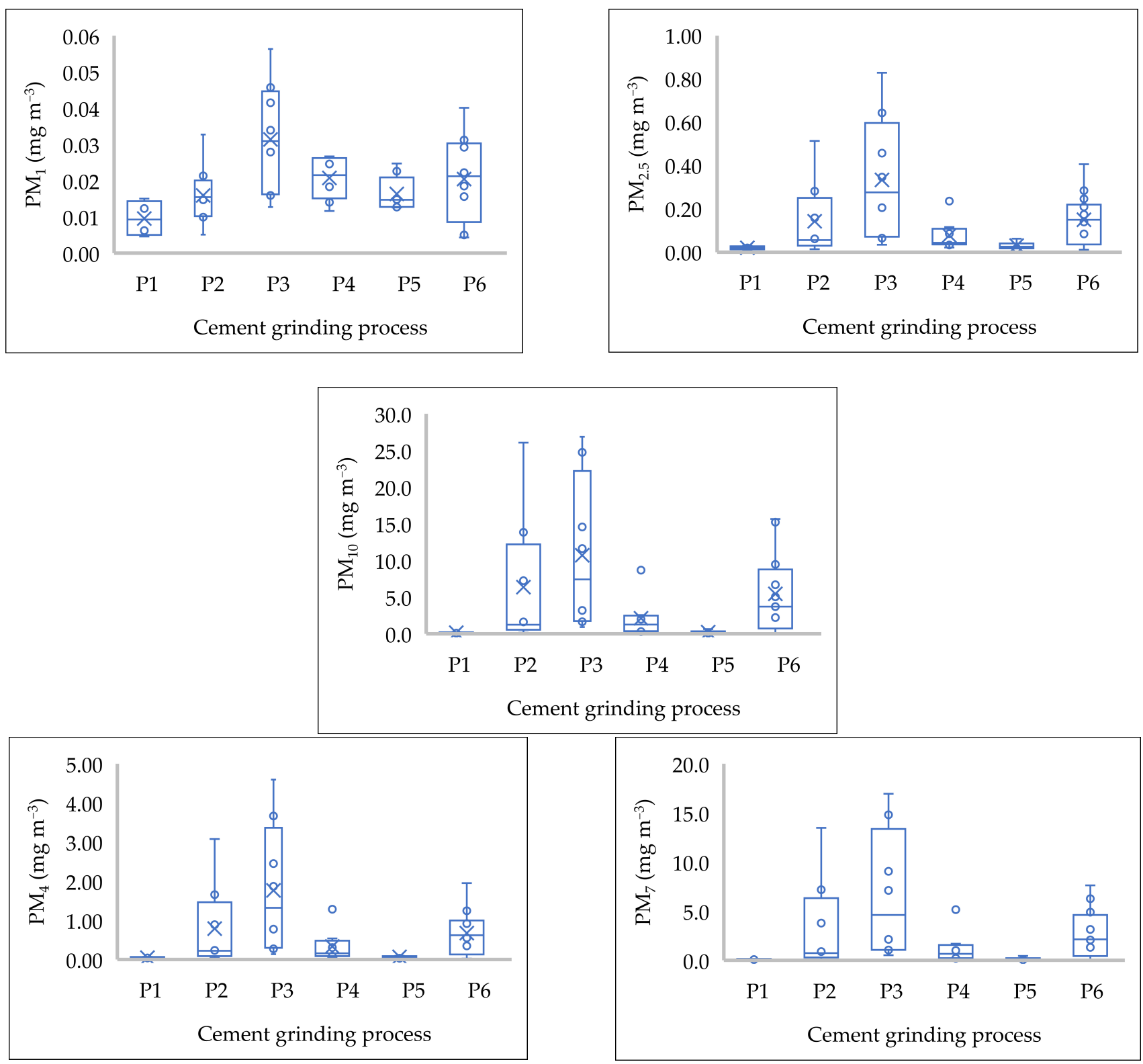

Figure 3. $\mathrm{PM}_{10-7-4-2.5-1}$ distribution in the cement grinding processes.

The mean (SD) levels of $\mathrm{PM}_{10-7-4}$ were 4.67 (7.04), 2.56 (3.91) and $0.66(0.98) \mathrm{mg} \mathrm{m}^{-3}$, respectively. The highest level of $\mathrm{PM}_{10-7-4}$ was measured at the connecting point between the feeding bin and the belt conveyor, a sub-process of pre-grinding process. The lowest level of $\mathrm{PM}_{10-7-4}$ was recorded at the bulk dispatch process. The mean (SD) $\mathrm{PM}_{10-7-4}$ level in the cement grinding processes was in jetty $\left(0.15(0.07), 0.10(0.05), 0.05(0.02) \mathrm{mg} \mathrm{m}^{-3}\right.$, respectively); raw material storage and handling (6.36 (9.28), $3.33(4.78), 0.79(1.08) \mathrm{mg} \mathrm{m}^{-3}$, respectively); pre-grinding (10.69 (10.58), $6.58(6.53), 1.76(1.69) \mathrm{mg} \mathrm{m}^{-3}$, respectively); cement grinding (2.12 (2.82), $1.23(1.68), 0.33(0.42) \mathrm{mg} \mathrm{m}^{-3}$, respectively); cement transferring and storage $\left(0.23(0.19), 0.15(0.13), 0.07(0.05) \mathrm{mg} \mathrm{m}^{-3}\right.$, respectively); and cement dispatch (5.44 (5.59), $2.64(2.36), 0.67(0.54) \mathrm{mg} \mathrm{m}^{-3}$, respectively). 
The peak mean levels of PMs factions were measured at the connecting point between the feeding bin and the belt conveyor, a sub-process of the pre-grinding process. The significant mean levels and wide range distribution of PM fractions were mainly measured at the pre-grinding, cement grinding, and cement dispatch process. In these processes, raw materials were crushed into small particles by the crusher and ball mill. In addition, the operation of the equipment in these processes generates heat, which reduces the moisture of the raw materials. These factors, in combination with the inefficient operation of the dust collectors, significantly contributed to the wide range distribution and levels of the PM fractions in cement grinding processes. There is currently no Vietnamese standard regulated for fine particles level in the indoor air environment.

The published works on the different fractions of particulate matter in the cement workplace environment are limited. Some researchers have reported the levels of $\mathrm{PM}_{10}$ and $\mathrm{PM}_{2.5}$ in the cement processes. A study reported the levels of $\mathrm{PM}_{10-2.5}$ in cement mill $\left(2.15,0.03 \mathrm{mg} \mathrm{m}^{-3}\right.$, respectively), loading area $\left(0.03,0.02 \mathrm{mg} \mathrm{m}^{-3}\right.$, respectively), and crusher $\left(0.25,0.07 \mathrm{mg} \mathrm{m}^{-3}\right.$, respectively) [41]. Another researcher reported the level of $\mathrm{PM}_{10-2.5}$ in the cement processes included cement mill $\left(0.59,0.87 \mathrm{mg} \mathrm{m}^{-3}\right.$, respectively), packing $\left(0.51,0.50 \mathrm{mg} \mathrm{m}^{-3}\right.$, respectively), and crusher $\left(1.55,1.80 \mathrm{mg} \mathrm{m}^{-3}\right.$, respectively) [42]. The levels of $\mathrm{PM}_{10-2.5}$ in this study were significantly higher than in the reported studies. Other researchers reported the level of $\mathrm{PM}_{10}, \mathrm{PM}_{2.5}$ in the ambient environment nearby the cement plants. The $\mathrm{PM}_{2.5}$ level was $0.03 \pm 0.01 \mathrm{mg} \mathrm{m}^{-3}$ and was in the range of $0.04-0.05 \mathrm{mg} \mathrm{m}^{-3}[43,44]$. The $\mathrm{PM}_{10}$ level was $0.03 \mathrm{mg} \mathrm{m}^{-3}$ and was in the range of 0.004-0.17 $\mathrm{mg} \mathrm{m}^{-3}[45,46]$. Therefore, the mentioned $\mathrm{PM}_{10-2.5}$ levels in the surrounding areas of the cement plant were significantly lower than the $\mathrm{PM}_{10-2.5}$ levels in the cement grinding processes in this study. For the PM in the ambient environment, a study reported the excessive $\mathrm{PM}_{10-2.5}$ concentrations were in the range of $0.06-0.10,0.02-0.04 \mathrm{mg} \mathrm{m}^{-3}$, respectively, and were associated with health risks [47]. Other work reported the highest average monthly concentrations of $\mathrm{PM}_{10-2.5}$ during dusty days were $0.3,0.07 \mathrm{mg} \mathrm{m}^{-3}$, respectively [48]. However, the concentration levels of $\mathrm{PM}_{10-2.5}$ in this study were much higher than the mentioned reports.

Cement workers are exposed to a wide range and significant levels of PM fractions during the working shift. The coarse fraction with a dynamic diameter between 10 and $2.5 \mu \mathrm{m}\left(\mathrm{PM}_{10-2.5}\right)$ remains in the upper part of the respiratory tract, and the fine particles $\left(\mathrm{PM}_{2.5}\right)$ can penetrate deeper into the lung system and cause health effects [49]. Prolonged exposure to particulate matter, especially fine particles, has been proven to have negative health effects on the exposed group [46,50-52]. Implementing an exposure reduction program to PM is needed to minimize the negative effects on workers' health.

\subsection{The Correlation between Concentration Levels of Respirable Dust and Silica Exposure}

The analysis results of the compositions and silica concentrations in the respirable dust samples at the study site are presented in Table 3.

Table 3. The compositions and silica concentrations in the respirable dust samples.

\begin{tabular}{|c|c|c|c|c|c|c|c|c|c|c|c|c|c|c|}
\hline \multirow{2}{*}{$\begin{array}{l}\text { Sampling } \\
\text { Location }\end{array}$} & \multicolumn{12}{|c|}{ Respirable Dust Composition (\%) } & \multirow{2}{*}{$\begin{array}{l}\text { Respirable Dust } \\
\text { Concentration } \\
\left(\mathrm{mg} \mathrm{m}^{-3}\right)\end{array}$} & \multirow{2}{*}{$\begin{array}{c}\text { Silica } \\
\text { Concentration } \\
\left(\mathrm{mg} \mathrm{m}^{-3}\right)\end{array}$} \\
\hline & $\mathrm{SiO}_{2}$ & $\mathrm{Al}_{2} \mathrm{O}_{3}$ & $\mathrm{Fe}_{2} \mathrm{O}_{3}$ & $\mathrm{CaO}$ & $\mathrm{MgO}$ & $\mathrm{SO}_{3}$ & $\mathrm{~K}_{2} \mathrm{O}$ & $\mathrm{Na}_{2} \mathrm{O}$ & $\mathrm{TiO}_{2}$ & $\mathrm{MnO}$ & $\mathrm{P}_{2} \mathrm{O}_{5}$ & $\mathrm{Cl}$ & & \\
\hline $\begin{array}{c}\text { Bulk } \\
\text { dispatch }\end{array}$ & 21.29 & 5.23 & 3.90 & 55.95 & 2.12 & 2.07 & 0.71 & 0.22 & 0.37 & 0.10 & 0.10 & 0.03 & 0.03 & 0.01 \\
\hline $\begin{array}{l}\text { Packing } \\
\text { machine }\end{array}$ & 20.77 & 5.75 & 3.73 & 52.57 & 2.59 & 2.24 & 0.64 & 0.38 & 0.47 & 0.10 & 0.31 & 0.14 & 0.66 & 0.14 \\
\hline $\begin{array}{l}\text { Barge bag } \\
\text { dispatch }\end{array}$ & 19.35 & 5.33 & 5.14 & 50.79 & 2.33 & 2.34 & 0.63 & 0.32 & 0.45 & 0.11 & 0.31 & 0.16 & 1.22 & 0.24 \\
\hline $\begin{array}{l}\text { Truck bag } \\
\text { dispatch }\end{array}$ & 20.97 & 5.77 & 3.40 & 51.87 & 2.64 & 2.31 & 0.64 & 0.38 & 0.44 & 0.11 & 0.30 & 0.18 & 0.77 & 0.16 \\
\hline $\begin{array}{l}\text { Cement } \\
\text { grinding }\end{array}$ & 19.62 & 4.89 & 2.88 & 55.88 & 2.12 & 1.66 & 0.72 & 0.27 & 0.34 & 0.08 & 0.30 & 0.25 & 0.33 & 0.06 \\
\hline
\end{tabular}


The measurement of silica (silicon dioxide) in respirable dust in the cement grinding processes showed that the range of silica content fluctuated between $19.35 \%$ and $21.29 \%$, and the mean (SD) composition of silicon dioxide was $20.4 \%(0.86)$. This finding was comparable with other studies in which silica composition in cement fluctuated from $21-22 \%$, and from $17-25 \%[53,54]$. In this study, the silica composition was not significantly different between the processes. The highest silica content was measured at the bulk dispatch $(21.29 \%)$, and followed by the truck loading (20.97\%), packing machine $(20.77 \%)$, cement mill (19.62\%), and barge dispatch (19.35\%). Because the silica composition is not significantly different amongst cement grinding processes or types of cement products, the level of silica exposure mainly depends on the concentration levels of respirable particles.

In this study, the respirable dust concentration level $\left(\mathrm{PM}_{4}\right)$ ranged between 0.02 and $4.59 \mathrm{mg} \mathrm{m}^{-3}$. The measurement recorded the highest level of respirable particles at the feeding bin and belt conveyor, which exceeded the PEL for an eight-hour working shift. The respirable concentration level at other processes was below the regulated exposure limit. Other studies published high concentration levels of the respirable dust concentration, such as packing machine $\left(4.5 \mathrm{mg} \mathrm{m}^{-3}\right)$, loading $\left(4.2 \mathrm{mg} \mathrm{m}^{-3}\right)$, crushing $\left(23 \mathrm{mg} \mathrm{m}^{-3}\right)$, mill $\left(6.7-7.1 \mathrm{mg} \mathrm{m}^{-3}\right)$, and raw mill $\left(43-47.6 \mathrm{mg} \mathrm{m}^{-3}\right)[13,14]$. A study conducted in a cement factory in Iran in 2019 figured out the range of respirable dust concentration was from $1.77 \mathrm{mg} \mathrm{m}^{-3}$ at cement mill to $6.12 \mathrm{mg} \mathrm{m}^{-3}$ at the crusher, packing and loading (3.4 $\left.\mathrm{mg} \mathrm{m}^{-3}\right)$, raw mill $\left(2.92 \mathrm{mg} \mathrm{m}^{-3}\right)$ [55]. The respirable dust concentration levels in this study were lower than the same processes in mentioned studies. However, the concentration levels of respirable dust can be significantly fluctuated within cement grinding processes depending on the level of operational control.

The results of Pearson analysis showed that there was a positive and significant correlation between the concentration levels of respirable dust and silica exposure in the cement grinding plant $(\mathrm{r}=0.99)$.

\section{Conclusions}

The study shows that the cement grinding plant has various dust sources that cement workers potentially expose daily. The TSP concentration in this study was in the range of 0.15 and $25.62 \mathrm{mg} \mathrm{m}^{-3}$. The results of the TSP measurement reveal that four out of six processes in the cement grinding plant exceeded the PEL for an 8-h working shift. The excessive processes include the storage and handling of raw materials, pre-grinding, cement grinding, and cement dispatch processes. Besides that, the study reports a wide range and significant levels of particulate matter fractions in the cement grinding processes. The peak mean levels of PMs factions were measured at the connecting point between the feeding bin and the belt conveyor, a sub-process of the pre-grinding process. The inefficient operation of the dust collector significantly contributed to the PM dispersion in this process. In addition, the study reveals a significant correlation between the concentration levels of respirable dust and silica exposure in the cement grinding plant $(r=0.99)$. Prolonged exposure to respirable particles containing silica and fine particles caused negative health effects on cement workers [56,57]. Therefore, the improvement of indoor air quality is needed to prevent negative health effects on cement workers. Firstly, the maintenance of the dust collectors, ducting hoods, needs to be addressed to reduce the dispersion of particulate matter fractions in cement grinding processes. Secondly, the automatic bag applicator is recommended to reduce the manual work and dust exposure for packer operators and stevedores. Thirdly, a complete dust management plan should be implemented to enhance the air quality in the workplace environment and prevent health effects on cement workers. The elements of a dust management plant include surveillance of dust source, dust measurement and monitoring, health surveillance, maintenance of dust collector and relevant equipment, housekeeping, training, working procedures, and provision of personal protective equipment. 
Author Contributions: The study was designed by T.T.; data collection, analysis, interpretation, and draft manuscript preparation were undertaken by T.T.; manuscript review and editing by P.K. and A.B. All authors have read and agreed to the published version of the manuscript.

Funding: This work was supported by VŠB-Technical University of Ostrava, Czech Republic, under Grant no. 2202 "Cooperation on the Disaster Prevention Community Project No. VJ01030011".

Institutional Review Board Statement: Not applicable.

Informed Consent Statement: Not applicable.

Data Availability Statement: Data from this study are available upon request.

Acknowledgments: The authors extend our sincere gratitude to the management of the study site for supporting this research. The authors would like to thank department representatives, the Quality Assurance team for their support in the data analysis of silica composition.

Conflicts of Interest: The authors have no conflict of interest to declare.

\section{References}

1. WHO Global Air Quality Guidelines. Particulate Matter (PM2.5 and PM10), Ozone, Nitrogen Dioxide, Sulfur Dioxide and Carbon Monoxide. Geneva: World Health Organization; 2021. Licence: CC BY-NC-SA 3.0 IGO. Available online: https://apps.who.int/ (accessed on 6 October 2021).

2. WHO-Occupational and Environmental Health Department of Protection of the Human Environment World Health Organization. WHO/SDE/OEH/99.14, Hazard Prevention and Control in the Work Environment: Airborne Dust; Occupational and Environmental Health Department of Protection of the Human Environment World Health Organization: Geneva, Switzerland, 1999.

3. Calvert, J.G. Glossary of atmospheric chemistry terms. Pure Appl. Chem. 1990, 62, 2167-2219. [CrossRef]

4. European Committee for Standardization. EN 481:1993-09, Workplace Atmospheres: Size Fraction Definitions for Measurement of Airborne Particles; Brussels: European Committee for Standardization: Brussels, Belgium, 1993.

5. Rushton, L. Chronic obstructive pulmonary disease and occupational exposure to silica. Rev. Environ. Health 2007, 22, 255-272. [CrossRef]

6. Anlar, H.G.; Bacanli, M.; İritaş, S.; Bal, C.; Kurt, T.; Tutkun, E.; Yilmaz, O.H.; Basaran, N. Effects of occupational silica exposure on oxidative stress and immune system parameters in ceramic workers in turkey. J. Toxicol. Environ. Health A 2017, 80, 688-696. [CrossRef]

7. Vacek, P.M.; Verma, D.K.; Graham, W.G.; Callas, P.W.; Bibbs, G.W. Mortality in Vermont granite workers and its association with silica exposure. Occup. Environ. Med. 2011, 68, 312-318. [CrossRef]

8. Park, R.; Rice, F.; Stayner, L.; Smith, R.; Gilbert, S.; Checkoway, H. Exposure to crystalline silica, silicosis, and lung disease other than cancer in diatomaceous earth industry workers: A quantitative risk assessment. Occup. Environ. Med. 2002, 59, 36-43. [CrossRef]

9. Parks, C.G.; Conrad, K.; Cooper, G.S. Occupational exposure to crystalline silica and autoimmune disease. Environ. Health Perspect. 1999, 107, 793-802.

10. Liu, K.; Mu, M.; Fang, K.; Qian, Y.; Xue, S.; Hu, W.; Ye, M. Occupational exposure to silica and risk of heart disease: A systematic review with meta-analysis. BMJ Open 2020, 10, e029653. [CrossRef]

11. Poornajaf, A.; Kakooei, H.; Hosseini, M.; Ferasati, F.; Kakaei, H. The Effect of Cement Dust on the Lung Function in a Cement Factory, Iran. Int. J. Occup. Hyg. 2010, 2, 74-78.

12. Mehta, P.; Monteiro, P. Concrete: Structure, Properties, and Materials, 2nd ed.; Prentice-Hall: Hoboken, NJ, USA, 1993.

13. Ballal, S.G.; Ahmed, H.O.; Ali, B.A.; Albar, A.A.; Alhasan, A.Y. Pulmonary Effects of Occupational Exposure to Portland Cement: A Study from Eastern Saudi Arabia. Int. J. Occup. Environ. Health 2004, 10, 272-277. [CrossRef]

14. Mirzaee, R.; Kebriaei, A.; Hashemi, S.; Sadeghi, M.; Shahrakipour, M. Effects of exposure to Portland cement dust on lung function in Portland cement factory workers in Khash, Iran. Iranian J. Environ. Health Sci. Eng. 2008, 5, 201-206.

15. Oleru, U.G. Pulmonary function and symptoms of Nigerian workers exposed to cement dust. Environ. Res. 1984, 33, 379-385. [CrossRef]

16. Vyskocil, J. The problem of chronic bronchitis in cement workers. Rev. Czechoslov. Med. 1962, 8, 38-52.

17. Izycki, J.; Gielec, L.; Sulkowski, W.; Kowalska, S. Respiratory tract in workers chronically exposed to cement dust. Med. Pr. 1979, 30, 241-246.

18. Laraqui Hossini, C.H.; Laraqui Hossini, O.; Rahhali, A.E.; Tripodi, D.; Caubet, A.; Belamallem, I.; Verger, C.; Hakam, K.; Alaoui Yazidi, A. Respiratory symptoms and ventilatory disorders among a group of cement workers in Morocco. Rev. Mal. Respir. 2002, 19, 183-189. [PubMed]

19. MacieJewska, A.; Bielichowska-Cybula, G. Biological effects of cement dust. Med. Pr. 1991, 42, $281-290$.

20. Vestbo, J.; Knudsen, K.M.; Raffn, E.; Korsgaard, B.; Rasmussen, F.V. Exposure to cement dust at a Portland cement factory and the risk of cancer. Br. J. Ind. Med. 1991, 48, 803-807. [CrossRef] 
21. Maier, H.; Gewelke, U.; Dietz, A.; Thamm, H.; Heller, W.D.; Weidauer, H. Laryngeal cancer and occupation: Results of the Heidelberg laryngeal cancer study. HNO 1992, 40, 44-51. [PubMed]

22. Noor, H.; Yap, C.L.; Zolkepli, O.; Faridah, M. Effect of exposure to dust on lung function of cement factory workers. Med. J. Malaysia 2000, 55, 51-57.

23. Meo, S.A. Chest radiological findings in Pakistani cement mill workers. Saudi Med. J. 2003, 24, 287-290.

24. Abou-Taleb, A.N.M.; Musaiger, A.O.; Abdelmoneim, R.B. Health status of cement workers in the United Arab Emirates. J. R. Soc. Health 1995, 115, 378-381. [CrossRef]

25. Ahmad, R.; Akhter, S. Effects of exposure to cement dust on hemoglobin concentration and total count of RBC in cement factory workers. J. Bangladesh Soc. Physiol. 2018, 13, 68-72. [CrossRef]

26. Initial Cement Industry Report. Available online: http://www.fpts.com.vn/FileStore2/ (accessed on 20 February 2021).

27. Decision No. 1266/QĐ-TTg. Approval of Construction Material Development Strategy in the Period from 2021 to 2030 in Vietnam. Available online: https:/ / thuvienphapluat.vn/Quyet-dinh-1266-QD-TTg-2020 (accessed on 29 December 2020).

28. Fuente, A.; Hickson, L. Noise-induced hearing loss in Asia. Int. J. Audiol. 2011, 50, 3-10. [CrossRef]

29. Thai, T.; Kučera, P.; Bernatik, A. Noise Pollution and Its Correlations with Occupational Noise-Induced Hearing Loss in Cement Plants in Vietnam. Int. J. Environ. Res. Public Health 2021, 18, 4229. [CrossRef]

30. Nguyen, D.T.; Pham, T.T. Air pollution in Ho Chi Minh City, Vietnam. In Proceedings of the Conference on Better Air Quality in Asian and Pacific Rim Cities (BAQ 2002), Hong Kong, China, 16-18 December 2002.

31. GeenID. Air Quality in Vietnam in 2017. Available online: http:/ / en.greenidvietnam.org.vn/ (accessed on 8 October 2021).

32. Ho, B.Q. Modeling PM10 in Ho Chi Minh City, Vietnam and evaluation of its impact on human health. Sustain. Environ. Res. 2017, 27, 95-102. [CrossRef]

33. Kim, K.H.; Kabir, E.; Kabir, S. A review on the human health impact of airborne particulate matter. Environ. Int. 2015, 74, 136-143. [CrossRef]

34. Luong, L.T.M.; Dang, T.N.; Huong, N.T.T.; Phung, D.; Tran, L.K.; Dung, D.V.; Thai, P.K. Particulate air pollution in Ho Chi Minh city and risk of hospital admission for acute lower respiratory infection (ALRI) among young children. Environ. Pollut. 2019, 257, 113424. [CrossRef] [PubMed]

35. Phung, D.; Hien, T.T.; Linh, H.N.; Luong, L.M.; Morawska, L.; Chu, C.; Binh, N.D.; Thai, P.K. Air pollution and risk of respiratory and cardiovascular hospitalizations in the most populous city in Vietnam. Sci. Total Environ. 2016, 557, 322-330. [CrossRef] [PubMed]

36. General Statistics Office. Ho Chi Minh Population 2020. Available online: https://www.gso.gov.vn/en/ (accessed on 8 October 2021).

37. National Technical Regulation. Permissible Exposure Limit Value of Dust at the Workplace: QCVN 02:2019/BYT. Available online: https:/ / thuvienphapluat.vn/QCVN02:2019/BYT (accessed on 17 May 2021).

38. OHSA. Occupational Safety and Health Standards No. 1910.1000—Air Contaminant. Available online: https://www.osha.gov/ laws-regs/regulations/standardnumber/1910/1910.1000 (accessed on 5 July 2021).

39. Mwaiselage, J.; Bråtveit, M.; Moen, B.; Yost, M. Variability in dust exposure in a cement factory in Tanzania. Ann. Occup. Hyg. 2005, 49, 511-519. [PubMed]

40. Kakooei, H.; Kakouei, A.A.; Poornajaf, A.; Ferasaty, F. Variability in total dust exposure in a cement factory. Ind. Health 2012, 50, 64-68. [CrossRef]

41. Al-Zboon, K.K. Indoor air quality in cement industry. Res. J. Chem. 2019, 9, 8-13.

42. Ahmad, W.; Nisa, S.; Nafees, M.; Hussain, R. Assessment of Particulate Matter (PM10 \& PM2.5) and Associated Health Problems in Different Areas of Cement Industry, Hattar, Haripur. J. Sci. Technol. 2015, 37, 7-15.

43. Mbelambela, E.P.; Muchanga, S.M.J.; Villanueva, A.F.; Eitoku, M.; Yasumitsu-Lovell, K.; Hirota, R.; Shimotake, Y.; Sokolo, G.J.; Mori, A.; Suganuma, N. Biomass energy, particulate matter $\left(\mathrm{PM}_{2.5}\right)$, and the prevalence of chronic obstructive pulmonary disease (COPD) among Congolese women living near of a cement plant, in Kongo Central Province. Environ. Sci. Pollut. Res. Int. 2020, 27, 40706-40714. [CrossRef] [PubMed]

44. Anchez-Sober, F.; Rovira, J.; Mari, M.; Sierra, J.; Nadal, M.; Domingo, J.; Schuhmacher, M. Main components and human health risks assessment of PM10, PM2.5, and PM1 in two areas influenced by cement plants. Atmos. Environ. 2015, 120, 109-116. [CrossRef]

45. Marcon, A.; Pesce, G.; Girardi, P.; Marchetti, P.; Blengio, G.; de Zolt Sappadina, S.; Falcone, S.; Frapporti, G.; Predicatori, F.; de Marco, R. Association between PM10 concentrations and school absences in proximity of a cement plant in northern Italy. Int. J. Hyg. Environ. Health 2014, 217, 386-391. [CrossRef]

46. Nkhama, E.; Ndhlovu, M.; Dvonch, J.T.; Lynam, M.; Mentz, G.; Siziya, S.; Voyi, K. Effects of Airborne Particulate Matter on Respiratory Health in a Community near a Cement Factory in Chilanga, Zambia: Results from a Panel Study. Int. J. Environ. Res. Public Health 2017, 14, 1351. [CrossRef] [PubMed]

47. Masud, Y.; Roohollah, R.; Ahmad, Z.; Mehdi, F.; Hosna, J. Exposure to high levels of PM2.5 and PM10 in the metropolis of Tehran and the associated health risks during 2016-2017. Microchem. J. 2019, 150, 104174. [CrossRef]

48. Ali, A.; Mehdi, F.; Ahmad, J.; Ahmad, Z.; Sajad, M. Particulate matter and bioaerosols during Middle East dust storms events in Ilam, Iran. Microchem. J. 2020, 152, 104280. [CrossRef] 
49. Anderson, J.O.; Thundiyil, J.G.; Stolbach, A. Clearing the air: A review of the effects of particulate matter air pollution on human health. J. Med. Toxicol. 2012, 8, 166-175. [CrossRef]

50. Kim, S.H.; Lee, C.G.; Song, H.S.; Lee, H.S.; Jung, M.S.; Kim, J.Y.; Park, C.H.; Ahn, S.C.; Yu, S.D. Ventilation impairment of residents around a cement plant. Ann. Occup. Environ. Med. 2015, 27, 3. [CrossRef]

51. Eom, S.Y.; Cho, E.B.; Oh, M.K.; Kweon, S.S.; Nam, H.S.; Kim, Y.D.; Kim, H. Increased incidence of respiratory tract cancers in people living near Portland cement plants in Korea. Int. Arch. Occup. Environ. Health 2017, 90, 859-864. [CrossRef]

52. Garcia-Perez, J.; Morales-Piga, A.; Gomez-Barroso, D.; Tamayo-Uria, I.; Pardo Romaguera, E.; Lopez-Abente, G.; Ramis, R. Risk of bone tumors in children and residential proximity to industrial and urban areas: New findings from a case-control study. Sci. Total Environ. 2017, 579, 333-1342. [CrossRef]

53. Ali, M.; Khan, I.; Hossain, M. Chemical Analysis of Ordinary Portland Cement of Bangladesh. Chem. Eng. Res. Bull. 2008, 12, 7-10. [CrossRef]

54. Health and Safety Executive. Portland Cement Dust. Criteria for an Occupational Exposure Limit; HSE Books: Suffolk, UK, 1994.

55. Omidianidost, A.; Gharavandi, S.; Azari, M.R.; Hashemian, A.H.; Ghasemkhani, M.; Rajati, F.; Jabari, M. Occupational Exposure to Respirable Dust, Crystalline Silica and Its Pulmonary Effects among Workers of a Cement Factory in Kermanshah, Iran. Tanaffos 2019, 18, 157-162. [PubMed]

56. Kakooei, H.; Gholami, A.; Ghasemkhani, M.; Hosseini, M.; Panahi, D.; Pouryaghoub, G. Dust exposure and respiratory health effects in cement production. Acta Med. Iran. 2012, 50, 122-127. [PubMed]

57. Johnson, C.R.; Knowles, J.; Rønnekleiv, B. Addressing the Health Risks of Silica Cement: A Custom Solution for Norway. In Proceedings of the SPE Bergen One Day Seminar, Bergen, Norway, 20 April 2016. [CrossRef] 